\title{
Managing Resources in Community Schools: An Accountability Practice in Paradox
}

\begin{abstract}
Scholars have raised two contradictory issues of particular relevance to current debates of accountability in the utilization of resources for service delivery in public schools. First, that inadequate resource resulted in the poor performance; second, that school actors lack accountability in managing the resources at their disposal. Corresponding to these views, empirical evidence suggests that school head's proactive initiatives find ways to fill up the resource gap; and at the same time, in doing so, school head's agency has created an invisible power structure putting his accountability practice in paradox. Building on these insights, this paper presents evidences from Nepali community schools on how head teacher's accountability as managing resources manifests in paradoxes. I argue that under the performativity of market-based accountability narrative, the school head's accountability is fluid and moving between the two paradoxical extremes of providing service or promoting dominance over other school actors.
\end{abstract}

Keywords: accountability, community school, resource, paradox.

\section{Introduction}

Resources are inputs used by the school actors to provide education services. Such resources include financial, physical, human, and information technology. According to Caldwell and Spinks (1992) resources in school are broadly conceptualized as knowledge, technology, power, material, time, assessment, information and finance. In addition, political and communication strategy of the school can be understood as school resources (Corduneanu-Huci, Mamilton, \& Ferrer, 2013). Since resources are scarce, how they should be managed in competing demands is a challenge in delivering public services (Fisher, 1998). Normally, it is assumed that more resources and spending produce better results. However, the research on this issue has not fully confirmed these beliefs (Leva ci' \& Vignoles 2002, as cited in Glover \& Levacic, 2007). Glover \& Levac $`$ ic (2007) in this reference argue for managing resources rather than focus on increasing the spending. Managing resources, thus, implies a cyclical process of obtaining, allocating, utilizing and reviewing the resources in an organization. In this process, not only how resources flow to the school but also how and by whom these are managed becomes a key concern from accountability perspective.

Generally, accountability in school means being responsive to and answerable for (Ackerman, 2004; Desai, 2013,; UNDP, 2006; Ranson, 2010) the activities performed by the school actors. UNESCO (2017) in Global Education Monitoring Report 2017 conceptualizes accountability as "a process aimed at helping actors meet responsibilities and reach goals" (p. xii). Being accountable in this sense entails a proactive moral responsibility making the actor/s accountable to oneself rather than to external mechanism. Bovens (2010) conceptualizes accountability along two dimensions: accountability as virtue and accountability as social relation or mechanism. From this perspective, school actors should possess certain attributes that account for his/her performance. Using these attributes s/he builds a social relationship with other actors in the school which is mediated through a mechanism of accountability in place. Dubnick (2014) regards accountability as cultural phenomena stating, "it is a lens through which we perceive, understand and shape all aspects of our social lives" (p. 37). The cultural manifestation of accountability implies that the concept of being accountable varies from one context to the other. Likewise, service delivery in education is the exchange of educational services between the service provider and the service seeker. While the school and school personnel are the service provider, the parents, students and community members are the service seeker or the beneficiary of the services rendered by the school. The notion of accountability is prominent in-service delivery.

Service delivery narratives in education highlight two-fold debate of accountability in education. First, that inadequate resource resulted in the weak delivery of education services (Fisher, 1998; Poyck, Koirala, Aryal \& Kishor, 2016); second, that school actors lack accountability in managing the resources (Government of Nepal, 2016) at their disposal. Paradoxically, there are instances that given the similar resource environment some public schools have demonstrated exemplary practices whereas others are 
unaware of their resource potentialities. Moreover, some other are found entrenched in malpractices and improper allocation of resources (Department of Education (DOE), 2015; Pherali, Smith, \& Vaux, 2011). Such scenario is evident of the under-use, over-use or misuse of resources in education. School functions within a triangular relationship of accountability, resource use, and service delivery. Luitel (2016) also explored how local resources were used in selected schools of Kathmandu valley. He reported that in almost all schools he explored the income of school rental was used in providing additional facilities to the school personnel rather than spending on improving the poor learning conditions. Being the executive head of the institution as well as the member secretary of the School Management Committee (SMC), the head teacher's role seemed significant (principal) in this regard.

In similar fashion, scholars have highlighted that the paradigm shifts taken place in public sector governance has placed the notion of accountability in a trap (Ambrosio, 2013; Bovens, 2010; Lindberg, 2013). They argue that in the context of market-centered governance, a public organization like schools are likely to be accountable to the customers who can pay the money rather than the common citizens (Bhattacharya, 2003; Haque, 2000; Walker, 2002; Ambrosio, 2013). Bovens (2007, 2010) opines that in the name of meeting market-based standards school actors are likely to meet accountability targets without any contribution to service delivery. Harvey (2006) is in favor of this argument stating that such a situation ultimately sidesteps the marginalized people by restoring the class power and class difference since it facilitates to channel the public wealth from poor to the rich. To add more, based on the experience from African countries, (Bruns, Filmer \& Patrinos, 2011) find that "the allocation of public education spending in developing countries often benefits the rich rather than the poor" (p. 7). It makes it clear that not only how resources are availed in the school but also how these resources are allocated and used is equally important in delivering the services. This aspect has been given less importance in accountability discourse.

This paper is the part of the larger study which illuminates what it means to be accountable for school head for delivering educational services. The key research questions of the study were: what is school actors' perception of head teacher's accountability for service delivery? How does the head teacher build accountability relations? And what paradoxes emerge in understanding and building accountability relations? Using the constructivist grounded theory approach, I explored four key accountability attributes of the head teacher. They were: accountability as managing resources, exercising autonomy, empowering actors and seeking integrity. In this paper, I illustrate how the school head's accountability as managing resources manifests in different ways along two paradoxical extremes. I argue that under the performativity of accountability narrative, the school head's accountability in using resources is in a pendular movement between the two paradoxical extremes of providing public services and creating a structure of dominance using his agency power. Drawing on conceptual framework of agency-structure perspective and 'karma-yoga' of ancient perspective, I categorically state the head teacher's accountability as managing resources in terms of four paradoxes.

Data for this paper have been drawn from a large dataset of my doctoral research. Believing on social construction of reality, the study followed a constructivist paradigm. Construction of knowledge through dialectical interaction between the researcher, the research participants and the research context made the study epistemologically subjectivist. Likewise, the nature of multiple social construction of reality gave the ontologically relativist identity of the study. I have collected the data from two community schools of Nepal: one comparatively resourceful locally and the other operated with limited resources. School management committee members, school head teacher (principal), teacher, parents, and students were the key research participants. These research participants were selected on the basis of the discussion with the local stakeholders of education. Datatexts were collected through interview, group discussion and observation of school events. Using the theoretical sampling procedure, I gathered the data-texts from 61 visits and 47 episodes of interview, group discussion and observation of the events. They were, in turn, analyzed using constant comparative inquiry of constructivist grounded theory approach, which was supplemented with ethnographic method. The meaning making process was done through integrative use of inductive, deductive and abductive reasoning. The categories or key dimensions of accountability have been co-constructed (Charmaz, 2011) through interaction between researcher and the participants. Data emerged from the bottom up process were categorized using inductive reasoning, categorical themes were verified and tested following the top-down process of deductive reasoning and the best choices of the emerging options was carried out using abducting reasoning process (Walton, 2004; Saldana, 2009; Charmaz, 2011). Quality of the study has been ensured against the quality criteria of constructivist grounded theory: credibility, originality, resonance, and usefulness discussed by Charmaz (2006).

The paper has been structured as follows. After the introduction, I first, present a brief overview of publicschool funding in Nepal. Following this, I deal with school actors' perception of accountability attribute as coordinating and negotiating for the resource. Then, I move on to accountability as manipulating the mind. After that, I discuss accountability as creating a synergy of diverse ideas. Next, I shed light on accountability as playing with parents' sentiments and expectation. Following this, I discuss the findings in terms of relevant theoretical insights and implications. Finally, I conclude the paper arguing that head teacher' accountability matters more than the availability of resources in community schools. 


\section{Paradox 1: \\ Accountability as Coordinating for Resources: Exercising Social Capital or Creating a Nexus of Dominance}

"Society does not become a jumble of juxtaposed atoms. Rather the members are united by ties which extend deeper and far beyond the short moments during which the exchange is made" (Durkheim, 1933, p. 226 cited in Field, 2012).

Placing my feet in Durkheim's shoes, I found intricate networks of relationships among the school actors against which their accountability was judged in managing resources in the community school. School head teacher demonstrated his accountability roles in his skill of coordinating and negotiating for generating the resources. This accountability property manifested in several strategic actions like accountability as making relations with local agencies and individuals; allocating and utilizing resources in an economic way; and compromising and negotiating for resource generation.

Identification of the potential source of funding was accountability attribute of the head teacher. School actors reported that government grants, parental support, and a donation from external agencies or individual were the major source of school funding. Government grants released by the District Education Office (DEO) has been the major source of funding. DEO and other nongovernment organization provided such grant to the school in various categories like temporary ' Rahat $^{l}$, teachers, teacher salary, scholarship, operation cost and the construction work. DEO would provide the budget to those who committed to reporting the completion of the work in time. In addition to the regular government grants, the urban school collected a significant amount of money from the rental of the commercial blocks. Revolving fund created by the fixed deposit of the parents has been another source of school income in the urban school. Head teacher utilized all these sources of funding for the school.

Parents and other actors also showed a skeptical view on head teacher's behavior. One of the SMC members in suburban school remarked that head teacher would call the meeting at the last minute of submitting the documents to the DEO and got the members to put a sign on it. When any member raised questions, he would say, "If you don't sign these papers. It means you are not cooperating me and going against the school's progress" (Field Note, December 7,2016 ). Fearing of public criticism, such people would quietly sign off the paper for school's sake. In similar fashion, in urban school head teacher coordinated with the officials in the central level ministry and brought money

1. Teachers in community school of Nepal are of different categories. Rahat teachers are those who get full salary form the government. Temporary teachers are those who get full salary and also, they occupy the permanent teacher post issued to school. Some teachers are community funded teachers who are paid by negotiation. Such teachers are normally underpaid. Other teachers belong to part-time teachers who teach the designated periods in the schools and move out. Such part-time teachers are paid either on course contract or on a period basis. for the school. In response to how the fund was allocated and utilized in the school, a senior teacher appreciated the head teacher's skill of identifying and obtaining resources. At the same time, he added that money collected in this way had been used in the construction of school building which might not be of any use later. He was saying so because he suspected that current overflow of external students would not last for a long time. School management committee members also were in favor of the head teacher. An experienced teacher who had been working in the suburban school for twelve years revealed the established practice of manipulating resources. He stated that management committee members would never go against the head teacher as he shared incentives to those who would not raise questions. Head teacher in this way seemed to be using his own discretion in the allocation of the funds collected from various sources in the school.

Making relations with local/national agencies and individuals had been instrumental in availing resources in school. In a suburban school, the head teacher and the management committee members made a connection with the pilgrims who visited a nearby site of religious significance. Philanthropic visitors would provide financial support to the school. The member of management committee would contact the donors and the local non-government organizations. The head teacher would convince the DEO personnel for teacher quotas and construction budget. School actors I interviewed agreed that accountable actors were those who could grab the fund for the school. Coordinating power and skill of the head teacher resulted in the collection of funding for the school. To quote the teacher in suburban school,

To be true, the head teacher has a good relationship with DEO office and other officials like resource persons, school supervisors, and accountants. He also convinces the parents and the management committee members. If there is good coordination, you know, really resource could be managed from any sources. (Field Note, December 7, 2016)

He maintained that head teacher's strategy of making good interpersonal relation and coordination with external officials as well as internal actors was the major source of school income. His personal relationship became instrumental in building parent's trust. One of the parents in suburban school observed, "He has contact with high officials and can bring budget from them. In his local language उनका बडे लोगोके साथ पहुँच है (he has good relation with the high officials)." (Field Note, April 11, 2017).

The urban school head teacher was affiliated to the political/professional organization and had easy access to high officials of the Ministry of Education and Finance. Being an influential member of the professional unions, DEO personnel also pursued him. He had a good rapport with the DEO as well. He convinced them to channelize the construction budget and teacher vacancies to the school. In these instances, head teachers were exercising his dominance over the other actors. According to the school actors, the head teacher worked in a network of 
like-minded people along lines of incentives and rentseeking $^{2}$ behavior. Using his interpersonal relations, he collected the fund for the school which was good for the school. However, how this fund was secured and used in the school had been a matter of concern from an accountability perspective. Head teachers in both sub/ urban schools identified where the funds came from and they devised their strategy of convincing the people by creating a network of a rent-seeking network.

Compromising and negotiating for resource generation was head teacher's another strategic action of accountability in school. The management committee member in suburban school expressed that the head teacher was bold and convincing to persuade others. "I like his way of 'getting things done by all means' and we have given him the discretion to do so. (Field Note, March 16, 2017). School actors trusted the head teacher's behavior. Taking advantage of this value, the head teacher used his discretion to negotiate for the resource generation and allocation. He would negotiate with the government officials to channelize the budget to his school and with the school management committee members for allocation of the collected budget.

Head teacher was proactive in generating resources for the school. What intent is working behind becomes a point of further exploration. However, other school actors' perception of him along with his beneficent contribution to school showed that he was utilizing this opportunity for creating his social identity as a social worker. I observed that in urban school head teacher would come to school early in the morning and remained there till the evening. In response to my curiosity why he was doing so actively for school, he replied,

I have no interest other than the school improvement. As a social servant school headship is an opportunity to earn my reputation through good results. When I produce good evidence of utilizing resources, there is no doubt, the donor/s, individual or agencies unhesitatingly offer their support to me. (Field Note, March 16, 2016).

He seemed bold and confident. The suburban school head teacher was also a locally rich man. He would spend time in coordinating with the DEO for generating funds and facilities for the school. In a similar vein, he contended that he would earn a social prestige by means of this headship post. This sounded a good value of a head teacher. It was on the basis of this value that parents had deep trust in them.

The expression "getting things done by all means" fascinated me much. The discretionary power and trust that was given to the head teacher by the school management committee and the parents made him negotiate with government officials to secure the fund for the school. Presumably, the strategy of getting things done by all means could be the reason why the government officials and other agencies preferred these schools to negotiate for funds. Apart from this, DEO's progress was dependent

2. Rent-seeking behavior is an economic activity where people seek benefits or incentives out of getting something done from the public resources. on the expenses furnished by the school. This motivated the DEO to seek a compatible school that could spend the budget in time and furnishes the documents of completion in time.

School head's personal relationship with high officials and donors, their affiliation with professional unions and their skill of negotiating enabled them to secure funding for the school. Both sub/urban schools were working in different financial context. Nevertheless, they employed the similar strategy of coordinating and negotiating for generating resources. They were keen to develop their social identity through this headship of the school. However, remarks from the critical actors evidenced that under the veil of social relationship they were exercising their social capital power to create a nexus of likeminded people ranging from the school to the DEO. It showed their dual role of accountability: being accountable to the public for generating resources and creating a network of the malfeasant team. It created a nexus of people who were likely to have control over school resource.

The shreds of evidence in this section showed, how head teacher's social capital worked well above the waterline and at the same time how his dominating power wielding exercise was perpetuating below the waterline. The following property of the core thematic category "accountability as manipulating the mind" would provide more instances of this kind.

\section{Paradox 2 \\ Accountability as Manipulating the Minds: Strengthening Academic Excellence or Developing Docile Followers}

"Teachers, I believe, are the most responsible and important members of society because their professional efforts affect the fate of the earth." - Helen Caldicott.

School actors', particularly the teachers', role was prominent in achieving and maintaining academic excellence in the school. The head teacher demonstrated his accountability for manipulating stamina of this academic force. He did so through the strategic actions like hiring competent teaching force, creating a challenging and cooperative learning environment, and motivating teachers for collective work. These features became his accountability attributes of his performance which contributed to the core category 'accountability as managing resources'.

Head teacher's skill of hiring the competent and motivated teaching force through better coordination worked as an accountability measure. Teachers were availed in the school in three ways: new permanent posting on the recommendation of the Teacher Service Commission, the transfer from other schools, and temporary recruitment by the school itself. In all (Government of Nepal, 2071) three modes, the head teacher's coordination or interpersonal skills again seemed significant. Head teachers in both urban and suburban schools repeated the strategies of convincing the DEOs to depute and transfer the competent teachers 
in their schools. The urban school head teacher, in this reference, recalled, "I normally give approval ${ }^{3}$ of transfer to teachers based on his/her merit and academic profile. When I hire a temporary teacher, I explore the talented person myself and encourage him/her to apply" (Field Note, December 8, 2016). Head teacher was indirectly making efforts to enter qualified teachers into the school. He knew if teachers were good at doing things, they could produce good results that eventually would attract the parents and students. The suburban head teacher also consented that he made a personal contact with the DEO and the candidate to enter the qualified teaching force. How these so-called qualified teachers were entered was a vital question where the formal procedure of teacher selection could become a showcase.

Harnessing temporary teachers' enthusiasm and stamina to stimulate other teachers' behavior created a challenging work context in the school. In suburban school all teachers except the four were temporary. They were doing really hard work. They were challenged to keep their job safe. A temporary female teacher in suburban school said, "We have to teach with preparation as we are instructed by the head teacher. If we do not teach accordingly, we are likely to lose our job." (Field Note, December 8, 2016). School management committee chair and the member also emphasized that teachers' duty was to teach well. The case of the urban school with respect to the temporary teacher was something different. In urban school out of 150 teachers, 36 were permanent. Parents and other actors didn't believe that permanent teachers worked well. "I am not sure if such a situation exists in this school once there are all permanent teachers", the Parent Teacher Association (PTA) chair shared his observation in the meeting. Another PTA member who had been working in the school as permanent teacher shared his experience, "All teachers are equally working well here. There is no excuse as head sir himself is working full time for school. Permanent or senior teachers have no option but to work on equal footing with the novice or temporary ones." (Field Note, December 10, 2016). This observation indicated that temporary teachers were the rich resources to make the school a success. It further showed that the combination of temporary teacher's enthusiasm and permanent teachers' maturity worked well in school improvement. Following this, the head teacher strategically formed the task teams, framed a working schedule and mixed-up the teachers.

Motivating and retaining the competent teachers was another challenge coped by the school. The head teacher in urban school had been able to hold the teachers together by creating an accountable space for them. He reported, "Strength of this school lies in the perseverance of teachers. All are given responsibility. If students fail in any subject, they have to give an answer to the head teacher and the parents" (Field Note, December 11, 2016). In suburban school, temporary teachers worked hard in the hope of

3. In order to get a transfer from one school to other, teachers are required to get a letter of approval from both sides (releasing school and welcoming school) in advance as an official requirement of formal procedure in DEO. obtaining a regular post later on. By creating an accountable space and opening up the possibilities, the head teacher strategically made them responsible for teaching and internally motivated. He added, "We have taught without any remuneration for two years in this school. We hope we get the government vacancy latter and if we do well our head teacher will certainly recommend us for that." (Field Note, December 11, 2016). When individual objective and identity is aligned with organization goal and objective, people got motivated. Teachers in urban schools felt pride in being a teacher of the reputed school. They wanted to gain their social popularity through school name and fame. The head teacher gave credit for success to the teachers. He was convinced that when teachers were trusted and given responsibility, they could make difference. It was not the externally imposed rules but the internally driven challenge made the teachers work.

Despite formal procedure of appointing teachers locally, head teachers and SMC seemed to be using their hidden power to acquire teachers strategically. Ex-SMC chair in urban school also revealed that sometime they had external political pressure in recruiting the teachers. In this case, they would compromise to select a teacher from among the candidates of a particular political group. Behind the veil of formal procedures head teachers was likely to hire like-minded teacher using their invisible power relations. Competent teachers were hired and availed, through personal approach and communication. This could create a team of docile followers who would seemingly loyal to the head teacher and the management committee. This showed that on the one hand, the head teacher was accountable to the public for hiring competent teachers. On the other hand, he worked in a network of his own. This network was created on the basis of common interests regarding the manipulation of teachers to create an obedient group of teachers who could follow them. To quote a critical teacher in urban school added, "Head teacher works in a group of his like-minded team. This includes teachers and some management committee members." (Field Note, March 2017). It put his accountability on the verge of making school vulnerable to collapse if the same combination of the network would not work later. The like-minded teams also worked in diversity. In the following section, I am going to show how seeking consensus within the diverse interests of the teachers put head teacher's accountability in paradox.

\section{Paradox 3 \\ Accountability as Getting Synergy of Diverse Interests: Seeking Consensus or Imposing Cut and Dried Recipe}

"The whole is greater than the sum of its parts." Aristotle

The strength of collective thinking as envisioned by Aristotle has been reflected in understanding accountability attributes of the school head teacher. Collective strength was created in the school through getting synergy of 
diverse interests. Synergy of interests was created through aligning political ideas and their creativity for organizational change, providing space for free interplay of multiple ideas among the school actors, keeping party politics away from the school environment. Similarly, the head teacher used the strategies of transforming politics of professional unions from curse to cure, and enhancing collective thinking and teamwork through like-minded team of formal and informal channels.

Aligning political ideas with organizational change and creativity worked an accountability feature in managing resources. Locals used schools as a platform of political debate in absence of local election for a long time. Many times, school actors got divided along political interests making school management a tough job. Diverse opinions flavored with party politics and personal interests worked as both opportunity and challenge for the change. Head teacher got the teachers to share their ideas freely and logically in the school. As I observed in the staff meeting in the urban school, the head teacher invited opinions from all teachers. Their ideas were linked to broader agenda of the school reform. The head teachers acknowledged that politics in the school was necessary providing it could be used for making learning environment better. Giving teachers time to share their agenda in meetings made them logical and responsible as well. They let the party politics remain away from the school. It was a strategy to keep the school away from the unnecessary dispute. This let the school actors think more creatively concentrating on genuine school agenda. An SMC member of sub-urban school expressed his conviction stating, "In our SMC meeting we are committed to remaining free of politics. If you want to do politics you can take it outside the school. We never invite any political figure in school events like opening or closing ceremony." (Field Note, April 16, 2017). Moreover, transforming politics from curse to cure has been the ability of head teacher which is a necessary virtue of accountability for school head. Head teachers were using political networking tactfully for generating resources and getting things done. All school actors had their attachment to political parties through professional organizations ${ }^{4}$. They had their personal relationship and attachment to influential leaders and officials. Head teacher, sometimes with support from SMC, contacted with upper-level officials in their political network and got funding endorsed for the school.

Getting things done through a like-minded team of people marked greater attention in accountability role of the head teacher. In suburban school, head teacher wished to form SMC from among those who would never like to go against him. In doing so he felt safe in making decisions. To quote a secondary teacher at sub-urban school, "SMCs are just thumb-stamp. Whatever head teacher does is ok for them. They believe head teacher always does everything in favor of the school." Parents interviewed also agreed to it. In such case, head teacher's integrity seemed crucial.

4. Although there is a legal provision of only one authorized professional union of teachers, in practice, there are as many professional organizations as the number of key political parties.
He could do well with such like-minded team without any obstruction. Such teams have been formed with external persons like DEO personnel as well. To quote an SMC member in suburban school, "Head Sir is very clever at making relations with DEO personnel. He offers good hospitality to them and makes them happy. This helps to get things done by these bureaucratic personnel." Likeminded teams are of various types. In school, normally teams were formed along political lines whereas, in DEO, a likeminded team was built based on interests and purpose. An influential ex-head teacher, who worked for quite a long time in the school also admitted saying, "Working with like-minded teams is a kind of academic politics. Politics can be used for school benefits." (Field Note, March 8, 2017). Head teacher's invisible power worked well in forming like-minded teams. A secondary teacher in urban school reported that head teacher would create such likeminded team, or a core team to make the decision about the school. This core team discussed the key output of the agenda in advance and presented it in the SMC meeting for endorsement. In both urban and suburban schools, the head teachers were working in teams: visible expert teams, hidden ideological teams, external purposive team. In two schools, the strategies and hidden intents were different. In suburban school, an external team was formed with a view to getting things done not through wielding personal power but to get the common interests fulfilled. In the urban school, the head teacher was making an external network on professional grounds and to some extent using his referent power (Northouse, 2000) as well.

Politics here has been dealt with both narrower and broader sense. Interpreting politics narrowly gave rise to party-biased ideological debate among the school actors affecting school activities. Fearing this, school actors did not let it enter into the school. Politics understood broadly was more than the party politics. It implied a kind of power sharing among the people that created a nexus of like-minded people. This indirect form of politics, without making any harm to school affairs, could be utilized for school's benefit. In suburban school, the former concept of politics has been used not to spoil the school environment whereas urban school also added the latter concept of politics and made synergy of diverse opinions getting individual ideas transformed for institutional or professional gain. With compared to sub-urban ${ }^{5}$ school, actors of urban school have more elaborated knowledge of politics making its creative use. In this view, transforming individual selfish interests into collective thinking has become a virtue of head teacher's accountability in school.

Working in like-minded teams of an informal channel and open sharing created space for transforming politics from curse to cure in the community school. However, in the guise of this open sharing practice, the head teacher was (re)producing the existing structure of domination and arbitrariness through symbolic force (Bourdieu, 1977;

\footnotetext{
5. Sub-urban school, in this paper, is known as the rural school which is comparatively disadvantaged from transportation, communication and other market access facilities. Urban school, on the other hand is more facilitated with such facilities and services.
} 
Dowding, 2008), patronage network and clientelism under the government agency (Corduneanu-Huci et al., 2013). Teachers' views were acknowledged in the meeting. However, in the end, the head teacher was reported to have imposed his or SMC's decisions prepared in advance. Just like aligning diverse interests to organization goral, understanding popular sentiments of the parents served as accountability attribute of the teacher.

\section{Paradox 4 \\ Accountability as Playing with Parents' Sentiments: Promoting Choice or Protecting Rights}

"The responsible administrator is one who is responsive to these two dominant factors: technical knowledge and popular sentiment." - Bertelli, 2012

Catching parents' sentiments and expectations was a basic strategy of the head teacher to build trust and earn goodwill. The sentiment here was realized as a kind of deeprooted feeling or opinion that the parents held about the fulfillment of their expectations from the school services. School head teacher was seen as a dynamic administrator displaying diverse technical and interpersonal skills. His professional skills technicality worked well when it was aligned with people's popular sentiment. This property was realized through critical reflecting of the situation and providing instructional choice to the parents.

Schools reflected on its internal and external environment and devised strategies to generate resources. To put suburban head teacher's voice, "Since I joined this school, I found no additional source of income. I convinced the parents, they became ready. We convinced DEO for construction quotas, Rahat teacher quotas, and other financial support. It was parents' voice". (Field Note, December 11, 2016). Parents have become the source of aspiration and encouragement for the head teacher to move ahead. In a similar vein, the actors of the urban school remarked that parental support had been the foundation of school progress. They added that in the past chaotic situation existed when the managers of school were against parents' will. Private schools were attracting the attention of parents. Schools reflected on the external situation. They caught the parents' sentiment of English medium instruction seen in the private schools.

At the same time when parents got attracted to the private schools, they were also willing to redirect their children from private to the community school. On reflecting the situation, head teachers found that parents were willing to send their children back to community schools for two prominent reasons. One, they expected at least similar standard of educational service as provided in the private school. Second, they wanted to secure special privilege given to community school graduates in post-school studies. Understanding such sentiment of the parents both urban and suburban community school arranged additional facilities. This caused the high student flow in these schools. Parents sending their wards in this way were willing to pay additional money to create proper learning arrangement in the school. This became the grand source of school income. From the financial perspective, this inflow of students became a grace for the school.

Providing instructional choice was another strategy of the school attached to catching the sentiment. The urban school adopted the strategies like giving a choice of both Nepali and English as the medium of instruction, teaching through ICT-based and student-centered project activities. Such strategic actions attracted the parents to come back to the community school. An aware group of parents who had sent their children to the boarding school in pursuit of the quality understood this strategy and redirected the children to the community school. In this way school and parents, both sides got benefitted. School collected the funds through donation and fees, and parents grabbed the private like facilities in relatively cheaper cost securing the special privileges. This is why sparingly the flow of the students popped up in upper grades of the secondary level. This was a play between the school and the comparatively aware group of people who could pay for the private school education. The school was seen being responsive to the need of these comparatively well-off parents.

School facilities or resources collected either through external or local sources in the community school were captured by a small group of parents who could pay either through student fee or through school donation or deposits. Once the facilities were occupied by the students transferred from other schools, other students who could not compete with new entrants remained marginalized. Profile of new entrants supported the parents' opinion that a great many new students belonged to business and service professions who could previously afford the private schooling. The choice was given to the parents through entrance tests and other fee-based strategies. It made the common people marginalized by making them deprived of having community school resources; and, thus, facilitating those who could pay the money for school services. In this way, head teacher's agency power was seen (re-)creating the structure of perpetuating inequality of access to public education. He was accountable for promoting choice for financially better-off people rather than protecting the rights of the common citizens.

Viewed the situation from vantage point of who benefitted from the situation, the adoption of the private-like practices could be seen as a strategic move to manipulate the parents' sentiments for school improvements. Parents belonging to remote areas remarked that they loved the community school; however, it was their compulsion to opt for private school as they found community school's performance no more satisfactory. When they found the community schools getting improved, they redirected their children. Head teachers and SMCs also claimed that enrolling students only in eighth/ninth grades for some time was a strategic move of the community school to catch the parents' sentiment and regain people's trust. The ex-SMC chair in urban school who was still active as a parent in school affairs elaborated the situation in this way.

We are well aware of the student flow in the upper 
grades. This situation has been utilized strategically to earn the goodwill and trust of the parents catching the mummydaddy sentiment of the parents and capturing the student flow from the hilly region. We are thinking of enrolling the student from lower grades as well." (Field Note, March $16,2017)$

This evidenced that school was utilizing the competitive practices as an opportunity to (re)gain parents' trust and school's goodwill. In the following section, I am going to discuss these paradoxes in terms of emerging theoretical perspectives.

\section{Discussions}

I attempted to unpack the paradoxical relationship between the use of resources and head teacher's accountability for service delivery in community school. Though the findings may resemble the previous results, they are different in terms of time, place and participants. Empirical evidence showed that government grant was the major source of funding in public schools. Apart from this, locally generated resources supplemented the government funding. In this entire process, head teacher's agency remained prominent. I argue that not only the cash property but also the proactive initiative of head teacher could explore the resources by utilizing the parents' sentiments and expectations. My study established that school capital or physical property was only visible and secondary source. More than this, the school head's proactive role demonstrated in his coordination and negotiation skill was the invisible and primary source of school funding.

I accept the two concepts of accountability put forward by Bovens (2010): accountability as virtue and accountability as mechanism. Adding further to this concept, I explored that in the context of managing school resources, head teacher's accountability manifested several attributes like accountability as coordinating and negotiating, manipulating the mind, getting synergy of diverse political interests and playing with the sentiment of parents. On the one end, he was accountable to the school actors or the public for obtaining and allocating resources, and on the other end, in doing so, he was creating a structure of dominance using his agency power. He created a nexus of people who, later on, were likely to have control over school resources. For example, under the property 'accountability as manipulating the mind, the head teacher availed the committed teachers, through personal approach and communication. This would create a like-minded team who would be loyal to him and the management committee. Head teacher utilized the ideological resource of the teachers by providing open space for democratic sharing in the meetings and letting so-called party politics ${ }^{6}$ out of the school. However, head teacher's tendency of getting cut and dried decisions endorsed by the group gave 6. In Nepal, Education Act 2028/Regulation 2059 (with amendments) provides for a single authoritative professional union of teachers. However, bearing different names of professional unions, teachers are split along the political party's ideological line. This tendency has often influenced the relationships among teachers and the working environment in the school. a sense of imposing his dominance over others using his discretion.

Using these attributes, he built a two-way accountability relationship with other actors. He displayed his accountability attributes in a pendular movement between two paradoxical extremes. Literally, a pendular movement is conceived of an apparatus consisting of an object mounted so that it swings freely under the influence of gravity. Metaphorically speaking, the invisible gravitational force that drives the head teacher's behavior, as evidenced in the data, was his drive for being a socially responsible figure and the bureaucratic mindset of Nepalese culture in which people associate their social prestige with power. Such a pendular movement put head teacher's accountability in a dualistic role of using his authority power proactively or being reactive to the existing culture and social norms. In this context he was using his agency to (re-)create the structure of domination and arbitrariness through symbolic force (Bourdieu, 1977; Dowding, 2008), patronage network and clientelism (Corduneanu-Huci, Mamilton \& Ferrer, 2013).

Influence of neo-liberal ideology in education challenged the government aided (community) schools to compete with their private (institutional) counterparts. As Turner (2008) puts, neo-liberalism is characterized by placing importance on market for efficiently allocating resources and safeguarding individual freedom, voluntary exchange of goods and services, minimal state intervention, and private property. The role of the state is to "secure social cohesion and stability through the prevention of individual liberty" (Turner, 2008, p. 4). In Nepal, community schools have not been fully left for the market practices (Boston, 2013). Historically, the financing has been the joint responsibility of the government and the community with varying degrees of practices overtimes. Since the government has loosened the rein of managing resources in public school (Ministry of Education, 2009), they are free to imitate, exercise and compete for market practices. In the context of Nepalese school education, I prefer to call the effect not of neo-liberalization but the effect of 'pseudo-neo-liberalization' in public schooling. This pseudo effect in community schooling is seen because of the open market situation in the private sector education. It is a false practice without any legitimate authority and mechanism. Education policy does not allow the public schools to go for market practices. The policy provisions overtimes have just opened up the way for wider community participation. What community schools have been doing was just the imitation of the private school's improved practices. Therefore, the community schools were not theoretically moving towards the market-based practices (Boston, 2013) rather the head teacher was being accountable to a certain group of people who are seeking for quality education.

The key theoretical construct emerged out of this core category were as follows. (i) School head's coordinating skill rather than the cash property was functioning as school property. Therefore, an accountable head teacher was one who could identify and generate funding from 
different sources. (ii) Head teachers' agency built on his social/cultural capital has created a structure of dominance placing him for duel accountability roles: being accountable to the public for generating resources and being accountable to the bureaucratic hierarchy and his network for fulfilling their interests. (iii) Imitation of market-based practices in delivering education services made head teacher accountable to a certain group of people who grabbed the school resources rather than to the public in general. (iv) Market-based open practices created both challenges and opportunities for the head teacher to build his accountability relations. It depends on accountability value of head teacher either to provide choice by perpetuating inequality or protect the rights of marginalized through introducing the better market practices in the school. It raised the need of an accountable leader in educational institutions.

Head teacher's accountability viewed in a pendular movement fascinated me to interpret with ancient philosophical ingredients of the Rig $\mathrm{Veda}^{7}$, which has been illustrated as a peace lesson (Shanti patha) in the Upanishads. One of the fascinating hymns reads like:

"वाड्मे मनसि प्रतिष्ठता मनो मे वाचि प्रतिष्ठितमाविराविर्य एधि । वे दस्य म आणीस्थ श्रुतं मे मा प्रहासीः ॥ अनेनाधीतेनाहोरात्रान् संदधाम्यृतं वदिष्यामि। सत्यं वदिष्यामि। तन्मामवतु। तद्वक्तारमवतु। अवतु मामवतु वक्तार मवतु वक्तारम् ॥ ॐँ० शान्तिः ॐँ॰ शान्तिः॥ ॐँ० शान्तिः॥" [Om vangme manasi pratisthita mano me wachi pratisthitamawirawirya edhi. Vedasya ma aanistha shrutam me ma prahasi. Anenashitenahoratran samdadhyamreitam vadisyami. Satyam vadisyami. Tanmawawatu. Tadwaktarmavatu. Awatu mamawatu vaktaram. Om Shanti. Om Shanti. Om Shanti.] (This Sanskrit verse means let my speech be established in my mind. Let my mind be established in my speech. Let me continuously live my days and nights in my studies. Let me speak the truth...) (Gita Press, 2014; Krishnaswamy, n.d.).

This Vedic hymn symbolizes moral accountability. Head teacher's behavior fluctuated between the two extremes of words and action. This hymn appeals the head teacher that his speech should be in congruence with his action. The problem of unaccountability arises when the person in charge of managing resource does not follow his/her words. The great message is that when the head teacher is true to his words, he is morally responsible for his duty. He has an inner mechanism to guide him. He is reflective and makes an adjustment of all emerging practices, demands and sentiments of the people for the betterment school. This ultimately leads to order and peace that is SHANTI (the ultimate peace) everywhere in the organization (the school).

\footnotetext{
7. The Rig Veda is one of the four canonical sacred texts Vedas in eastern philosophy. It is an ancient collection of hymns dedicated to the adoration of the deities. It personifies the physical power of nature and symbolizes the spiritual links that bind the human and the divine. The hymns composed of poetic forms appeal to the human beings.
}

\section{Conclusion and implication}

Accountability role of the school head was like a pendular movement moving back and forth between two contradictory extremes. Corresponding to the properties of managing resources, these extremes were: (i) accountability as earning social identity through exercise of social capital or exercising dominance over the school actors, (ii) accountability as promoting excellence through committed academic force or creating space for likeminded docile followers, (iii) accountability as converting politics from curse to cure or imposing discretionary power, and (iv) accountability as providing choice to the parents or perpetuating inequality of educational opportunity. This pendular movement brought forth the two-way contradictory accountability roles of the school head. On the one hand, the head teacher was accountable to the public or the school actors for managing resources in the school through coordinating, availing teachers, creating a synergy of ideas and catching parents' sentiments. On the other hand, his accountability was disguised under the veil of invisible power exercise to give way for the perpetuation of dominance and inequality. Such paradoxes have created both challenges and opportunities for the school actors to manage resources for delivering better educational services in the community school. It is a challenge in that head teacher is likely to lead the school to serve the affluent group of people and often ending up with corruption and arbitrary practices. It is an opportunity in the sense that market-based pseudo-neoliberal practices could be utilized as a strategy to harness parents' capacity for managing resources in the community school. These contradictory findings have implication for devising specific accountability measures of head teacher in the community school with a particular reference to managing resources by the local community compatible with the federal structure of Nepal. In addition, it has opened up a wider area of research on how these paradoxical accountability measures best fit in the local dynamics of the social structure.

\section{Acknowledgement:}

The author is thankful to DANIDA Fellowship Center for providing the scholarship for his doctoral study.

\section{Funding:}

This article is a part of author's doctoral study which has been funded by DANIDA Fellowship Center Denmark.

\section{Ethical approval for the research:}

Ethical approval imbedded in the research proposal has been approved by the Research Committee at Kathmandu University School of Education.

\section{Conflict of Interest:}

There is no conflict of interests.

Ethical Conduct of Research:

I declare that this research has been conducted ethically 
ensuring the confidentiality of the participants and reflecting upon the positionality of the author as a researcher.

\section{References}

Ackerman, J. (2004). State-society synergy for accountability: Lessons for the World Bank. The World Bank.

Ambrosio, J. (2013). Neoliberalism and accountability in public education. Educational Studies, 49(4), 316-333. https://doi:10.1080/00131946.2013.783835

Bertelli, A. M. (2012). The political economy of public sector governance. Cambridge University Press.

Bhattacharya, M. (2003). The nexus between accountability and good governance: conceptual and practical issues. In P. Sahni \& U. Medury (Eds.), Governance for Development (pp. 33-47). Prentice-Hall of India Private Limited.

Boston, J. (2013). Basic NPM ideas and their development. In T. Christensen \& P. Lægreid (Eds.), The Ashgate Research Companion to New Public Management. MPG Books Group.

Bourdieu, P. (1977). Outline of a theory of practice. Cambridge Studies in Social Anthropology, 16(16), 248. https://doi: 10.1590/S0103-20702013000100001

Bovens, M. (2007). Analysing and Assessing Accountability: A Conceptual Framework. European Law Journal, 13(4), 447-468. https://doi: 10.1111/j.1468-0386.2007.00378.x

Bovens, M. (2010). Two concepts of accountability: Accountability as a virtue and as a Mechanism. West European Politics, 33(5), 946-967. https://doi: 10.1080/01402382.2010.486119

Bruns; B., Filmer; D., \& Patrinos, H. A. (2011). Making schools work: New evidence on accountability reforms. The World Bank.

Caldwell, B. J., \& Spinks, J. M. (1992). Leading the selfmanaging school. Falmer Press.

Charmaz, K. (2011). Grounded theory methods in social justice research. In N. K. Y. S. L. Denzin; (Ed.), The SAGE Handbook of Qualitative Research (4th ed., pp. 359-380) Sage Publications Ltd.

Corduneanu-Huci, C., Mamilton, A., \& Ferrer, M. I. (2013). Understanding policy change: how to apply political economy concepts in practice. The World Bank. https://doi.10.1596/978-0-8213-9538-7

Department of Edcation. (2015). Status report 2014/15. Author.

Desai, J. P. (2013). Accountability: Angst, awareness, action. Pearson.

DfID (2009). Political Economy Analysis: How to Note. A DFID Practice Paper, (July), 1-29. Retrieved from http://www.odi.org/sites/odi.org.uk/files

Dowding, K. (2008). Agency and structure: Interpreting power relationships. Journal of Power, 1(1), 21-36. https://doi.10.1080/17540290801943380

Dubnick, M. J. (2014). Accountability as a cultural keyword. In M. Bovens, R. E. Goodin \& T. Schillemans (Eds.), The Handbook of Public Accountability (441-
445). Oxford University Press.

Field, J. (2012). Social capital (2nd ed.). Routledge.

Fisher, C. M. (1998). Resource allocation in the public sector: values, priorities, and markets in the management of public services. Routledge.

Gita Press. (2016). कल्याण, उपनिषद् अड्र (Kalyan, UpanishadIssue) Code-659.

Glover, D., \& Levacic, R. (2007). Educational resource management an international perspective. University of London. Retrieved from www.ioe.ac.uk/publications

Government of Nepal. (2016). School sector development plan 2016-2023. Minis.

Government of Nepal. (2071). Education act 2028 (with amendments) and education regulation (with amendments) 2059. Government of Nepal.

Haque, M. S. (2000). Significance of accountability under the new approach to public governance. International Review of Administrative Sciences, 66(200012), 599617.

Harvey, D. (2006). Neo-liberalism as creative destruction. Geography and Power, the Power of Geography, 88(2), 145-158.

Krishnaswamy, N. (n.d.). The Rig Veda for the first time reader. A Vidya Vrikshah Publication. Retrieved from http://www.vidyavrikshah.org/THERIGVEDA.pdf

Lindberg, S. I. (2013). Mapping accountability: core concept and subtypes. International Review of Administrative Sciences, 79(2), 202-226. https://doi. $10.1177 / 0020852313477761$

Luitel, G. (2016). School's land rent used as employment salary: Nothing for the students. Shikshak Jestha 2073. Available at www.teacher.org.np

Ministry of Education. (1971). The national education system plan for 1971-76. Ministry of Education.

Ministry of Education. (2009). Compendium on education policy in Nepal. Ministry of Education.

Northouse P. G. (2013). Leadership: theory and practice (6th ed.). SAGE Publication India Pvt. Ltd.

Pherali, T. J., Smith, A., \& Vaux, T. (2011). A political economy analysis of education in Nepal. Retrieved from http://uir.ulster.ac.uk/30667/1/Pherali_Smith_ Vaux

Poyck, M. C., Koirala, B. N., Aryal, P. N., \& Kishor, S. N. (2016). Joint evaluation of nepal's school sector reform plan 2009-2016. Ministry of Education.

Ranson, S. (2010). Public accountability in the age of neo - liberal governance. Journal of Education Policy, 37 41. https://doi.10.1080/0268093032000124848

Saldaña, J. (2009). The coding manual for qualitative researchers. SAGE Publications Ltd.

Turner, R. S. (2008). Neoliberal ideology history, concepts and policies. Edinburgh University Press Ltd.

UNDP. (2006). Mutual accountability mechanisms: Accountability, voice and responsiveness. Conference Paper. UNDP. Retrieved from www.capacity.undp.org.

UNESCO. (2017). Global education monitoring report 2017/18. Accountability in education: Meeting our commitments. UNESCO.

Walker, P.(2002). Understanding accountability: theoretical 
models and their implications for social service organisations. Social Policy and Administration, 36(1), 62-75. https://doi. 10.1111/1467-9515.00270

Walton, D. (2004). Abductive reasoning. The University of Alabama Press.

Kul Prasad Khanal, PhD is MPhil in Educational Leadership from Tribhuvan University. He joined his $\mathrm{PhD}$ study in Kathmandu University in 2016 under the DANIDA Fellowship. As part of his study, he studied the dedicated research courses in Arhus University, Denmark as well. He has just completed his doctoral study defending the thesis entitled "Exploring Dimensions of Accountability in Community Schools: A Constructivist Grounded Theory Inquiry". He has also published other articles based on his research findings and methodology. Professionally, he works for the Government of Nepal as an education manager. His passion is on linking ancient (eastern) and modern (western) theoretical perspectives in researching the issues of governance and accountability in education.

Email: ku1016@kusoed.edu.np 